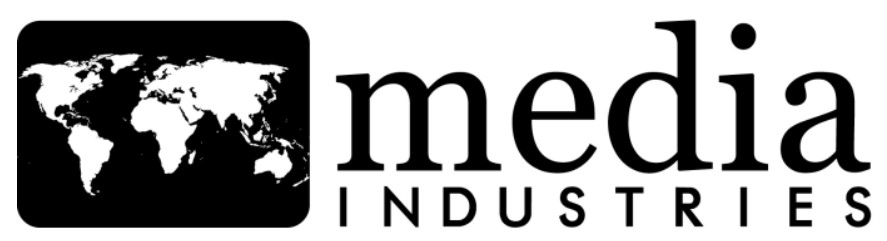

\title{
Advertising, the Media, and Globalization
}

\author{
John Sinclair ${ }^{1}$ \\ University of Melbourne \\ j.sinclair [AT] unimelb.edu.au
}

\begin{abstract}
:
Advertising is a crucial media industry, not only in its own right but also because of the intermediary structural relation it holds between the commercial media on one hand and the consumer goods and service industries on the other. This can be conceived as a manufacturing-marketingmedia complex. However, the traditional business model that facilitated this relationship in the mass media era is now under challenge from the new forms of social communication afforded by the internet. Accordingly, such a fundamental transformation forces a critical review of how advertising has been understood. This essay explains how former approaches such as the semiological analysis of advertisements, the Marxist political economy of value, ethnographic studies of advertising practice, and the "cultural turn" in social theory have all been superseded to a greater or lesser extent by the reorientation of advertising within a broader conceptual landscape of consumer culture, and by contemporary theory and research on branding. Furthermore, attention is given to the historical globalization of the corporations that own the brands and the advertising industry's response, which has been to consolidate into a small number of global umbrella corporations that coordinate and manage a host of specialist divisions across the whole field of "integrated marketing communications."
\end{abstract}

Keywords: Advertising, Globalization, Internet, Marketing, Social Media

The media industries are different from other industries because of their privileged place in social communication and the perception that they wield extensive influence on public opinion, cultural norms and values, and the popular imaginary. This truism applies particularly to the advertising industry, for not only does advertising have a high visibility in the cultural environment: it is also the most vital source of the revenue that supports and motivates the vast majority of commercial media. It could even be said that advertising is the media industry that stands behind all the other media industries. However, research approaches of past decades have tended to concentrate upon the products of the advertising industry-that is, advertisements and their cultural significance - rather than penetrating beyond to the industry as such, including its political and cultural economy; the relations between advertisers, advertising agencies, and the media; and actual advertising practices. More contemporary 
research has focused directly on these fundamentals, particularly in the context of globalization and the complex transition from "old" to "new" media. ${ }^{2}$

The very meaning of "advertising" is in flux, for the advent of the internet has transformed the character of advertising media as we have known it. The comfortable relationship between advertisers, agencies, and media that existed throughout the golden age of mass media in decades past - in which the media would offer content that could attract audiences so as to sell access to those audiences to advertisers via the agencies - is a business model that is now under severe pressure. The interactive properties of the internet, with the affordances of social networking and direct commercial transactions, have precipitated a shift in the balance of power between advertisers and consumers. These properties have also caused advertising revenue for television, still the dominant medium for advertising in most national markets, to grow more slowly as advertisers increasingly favor the internet. Meanwhile, on the internet itself, emergent business models compete for hegemony.

With the growth of the internet, it becomes more evident that advertising is just the most visible and public dimension of a much broader, but still quite familiar, set of practices intent upon harnessing our ways of life for commercial purposes. These practices include sponsorship, notably of sport and the arts; in-store displays, sales promotions, competitions and giveaways; and direct marketing, such as telemarketing. In the past, media advertising was referred to in the industry as "above the line," while the various forms of nonmedia marketing, such as those just mentioned, were deemed "below the line." However, the line has been crisscrossed so much now that it is obliterated. Not only is media advertising ever more incorporated into sales promotions - for instance, television commercials promoting giveaway toys in McDonald's but advertising campaigns are now devised on a "cross-platform" basis, meaning that such campaigns are mounted across traditional media, the internet, and perhaps other, more direct "touchpoints" where they can reach prospective consumers. Marketing practitioners and textbooks now tend to conceive of advertising in the context of what they like to call "integrated marketing communications." This may sound like empty industry hype, but the phrase does express how advertising is now linked strategically to the other dimensions of marketing, and to other forms of promotion. ${ }^{3}$

Given the triumph of neoliberal ideology in recent decades, it may be difficult to appreciate that there was a time when Marxism-or at least, a "cultural" version of it-was extremely influential in setting the agenda for media and communication research. In conjunction with feminist perspectives, this neo-Marxism generated a great deal of research and theoretical critique in the 1980s, when advertising was considered to be a prime instrument for the reproduction of consumer capitalism and patriarchy, as revealed by semiological-structuralist analysis. The classic example is Judith Williamson's Decoding Advertisements. 4 This type of scholarship put emphasis on advertisements rather than advertising as such, a focus of inquiry that was interesting and useful for a time but that ultimately exhausted itself. A version of Marxism more attuned to political economy instead paid attention to advertising's role in "commodification," that is, how advertisements endow goods with an "exchange value" beyond their actual usefulness. This concept is still part of the critical lexicon, but is not so much a heuristic and analytic concept as a rhetorical trope used to denounce all cultural forms in which commerce encroaches upon spheres of life where it ought not belong. 
In the 1990s, the study of advertising came to be seen within a larger, more inclusive context, framed within a broad critique of "consumer culture" and the society that supported it. The same decade saw attention shift to the dynamics of the advertising agency. Several researchers, such as William Mazzarella, ${ }^{5}$ drew upon anthropology, employing that discipline's characteristic methodology of ethnography, usually by working in advertising agencies as participant-observers. This work represented something of a focal shift, centered less on advertising and the media as such and more on advertising practice.

A prominent theoretical contribution came from Scott Lash and John Urry, who argued that the economy and culture were becoming ever more integrated. ${ }^{6}$ They particularly saw a "culturalization" of economic production, meaning that goods and services were designed to attract certain kinds of consumers and to fit with their lifestyles. This work typified the "cultural turn" of the 1990s, a broad movement away from political economy in favor of more emphasis on systems of symbolic meaning and the reflexivity of subjects within culture, a trend that attracted attention to the study of advertising as the complex fusion of economy and culture. Prior to the cultural turn, it was sufficient to "get a life," but both the discourse of marketing and its critique promoted the idea that what we each needed was a lifestyle as a way of defining our individuality by knowingly constructing a distinctive pattern of consumption for ourselves.

However, a recurrent criticism of Lash and Urry's thesis about the "aestheticization" of goods and services in "consumer society" is that it is too "epochal" to posit as a new and decisive phase in the history of capitalist modernity. ${ }^{7}$ If it makes any sense at all to talk about a consumer society, critics say, its genesis is better thought of, and studied empirically, as the result of incremental shifts rather than a qualitative, epoch-defining leap. There is also the issue of the complex moral baggage carried not so much by the consumer culture-society couplet in itself as by consumerism, the total ethos of social values on which it is said to rest. This is a term familiar from both academic and popular critiques of how we live now, and used by both conservative and progressive sides of the spectrum. Yet it is a normative term, almost devoid of analytic meaning. Everybody is opposed to consumerism, from the Pope to Occupy Wall Street.

The 2000s have seen a shift of attention toward a quite specific marketing and advertising practice, namely that of branding, particularly in its relation to popular culture and new media. Some of the best contemporary academic work is on branding, rather than on advertising as such. ${ }^{8}$ Particularly since the era of large-scale corporate takeovers of brands in the 1980s, advertising has become consciously harnessed to the process of branding. More than uniquely identifying a product or its manufacturer, advertising enables brands to acquire cultural meanings, such as status distinctions (Harrod's versus Marks \& Spencer), associations with certain kinds of people (the Marlboro man), and even something like their own personalities. Just as mediated popular culture sustains a world of celebrities, so it does also for the world of goods. However, if brands are the celebrities, then commodities are the masses - and, as Marx could not have anticipated, it is actually brands, not commodities, that are fetishized. Modernday Marxists can agree that branding contributes to a mystique that conceals the value of the labor that made the product: branding is a process through which commodification takes place.

Indeed, one influential theorist of branding, Adam Arvidsson, invokes "autonomous" Marxism to make the argument that-although it is people (whether a nation or a subculture) who create "trust, affect and shared meanings" - what brand marketers do is to pick up on these meanings 
and exploit them by associating these meanings with particular products and services. ${ }^{9}$ This is a capitalism that is more reflexive in the sense that it recognizes the rise of an independent popular culture but seeks to bring it under the control of commercial interests. Consumers, in this view, are more reflexive in understanding their own responses in relation to advertised goods. Yet Arvidsson also acknowledges that consumer perceptions are "beyond the direct control of capital."10 Far from imposing brand images upon unwitting targets, brand managers have to protect their brands from falling victim to ridicule or disrepute. Young consumers in particular are inclined to participate in ruthless parodies and spoofs of branded advertising that they discern to be manipulative and inauthentic, and new social media such as YouTube, Facebook, and Twitter allow the diffusion of such material on a global scale. At the same time, advertisers and their agencies are fascinated by the internet's ability not only to target young consumers but also to exploit their social networking behavior, so they play the dangerous game of strategically planting advertising or other marketing material on the internet that they hope will go viral, that is, be picked up and passed on by users, thus creating buzz around the brand.

Many, perhaps most, of the brand names that we know via advertising and other modes of marketing in our national markets are in fact owned by global corporations. Some of these corporations are companies that grew from local to national scale, mainly in the United States and Western European countries, becoming in the 1960s and 1970s what were called the multinational, or transnational, corporations. Others, the colossi of the internet age, have become global only in recent decades, notably Google, Microsoft, and Apple. Among all these, the main clients of the advertising agencies and big spenders on media are the manufacturers of "FMCG" (fast-moving consumer goods), or everyday packaged food, household, and personal products. Corporations like Procter \& Gamble and Unilever, both with hundreds of brands under their corporate umbrellas, can be found on the lists of biggest advertisers in most countries of the world.

In step with the globalization of such clients and the media carrying their advertising, the advertising agency business itself has become highly globalized in its organization. The real crucible of the present era was the 1980s, when the UK-, France-, and Japan-based agencies rose to challenge US industry domination at a global level. Certain British agencies, buoyed by stock market "financialization," bought out several Madison Avenue agencies. This was the beginning of globalization proper. The putative national origin of agencies became less important than the combined interpenetration of capital from different national origins; and more importantly, a completely new stratospheric level of ownership and management was created in the form of the global advertising group, or "mega-group." The world advertising industry has since evolved into a small number of complexly integrated holding groups that, to use the trade discourse, incorporate "creative" advertising agency networks along with "mediabuying" specialist agencies, and businesses in a series of related marketing "disciplines," which include internet or digital advertising, as well as public relations, market research, direct mail, and similar "marketing services." These structures are a manifestation of how "integrated marketing communications" have eclipsed the mediacentric advertising of the past.

Indeed, with the remarkable growth of social media and other internet use, digital advertising is attracting ever more advertising revenue. Apart from the crisis this trend has presented for "legacy" media, particularly print, it has given rise to more commercio-technical areas of advertising practice, such as in the exploitation of "big data," and in "programmatic 
advertising," the computer-programmed placement of advertisements. The avid attention that advertising agencies are now giving to digital media is an index of the degree to which the once-comfortable relations between agencies, media, and advertisers now have been destabilized as the era of mass media morphs into the age of the algorithm.

1 Professor John Sinclair is Honorary Professorial Fellow in the School of Historical and Philosophical Studies at the University of Melbourne. His published work covers various aspects of the internationalization of the media and communication industries, with a special emphasis on Asia and Latin America. His recent books include Advertising, the Media and Globalisation; the coauthored Latin American Television Industries; and the coedited Consumer Culture in Latin America. He has held visiting professorships at leading universities in Europe and the United States, is on the editorial advisory boards of various international journals, and is active in professional organisations.

2 John Sinclair, Advertising, the Media and Globalisation: A World in Motion (New York: Routledge, 2012).

3 George E. Belch, Michael Belch, Gayle Kerr, and Irene Powell, Advertising and Promotion: An Integrated Marketing Communication Perspective (Sydney: McGraw Hill Australia, 2014, 3e).

4 Judith Williamson, Decoding Advertisements (London: Marion Boyars, 1978).

5 William Mazzarella, Shovelling Smoke: Advertising and Globalization in Contemporary India (Durham, NC: Duke University Press, 2003).

6 Scott Lash and John Urry, Economies of Signs and Space (London: Sage, 1994).

7 Liz McFall, Advertising: A Cultural Economy (London: Sage, 2004), 99.

8 Melissa Aronczyk and Devon Powers, eds., Blowing Up the Brand (New York: Peter Lang, 2010).

9 Adam Arvidsson, "Brands: A Critical Perspective," Journal of Consumer Culture 5 (2005): 236-37.

10 Ibid., 242.

\section{Bibliography}

Aronczyk, Melissa and Devon Powers, eds. Blowing Up the Brand. New York: Peter Lang, 2010.

Arvidsson, Adam. “Brands: A Critical Perspective.” Journal of Consumer Culture 5 (2005): 235-58.

Belch, George E., Michael Belch, Gayle Kerr, and Irene Powell. Advertising and Promotion: An

Integrated Marketing Communication Perspective. Sydney: McGraw Hill Australia, 2014 3e.

Lash, Scott, and John Urry. Economies of Signs and Space. London: Sage, 1994.

Mazzarella, William. Shovelling Smoke: Advertising and Globalization in Contemporary India.

Durham, NC: Duke University Press, 2003. 
McFall, Liz. Advertising: A Cultural Economy. London: Sage, 2004.

Sinclair, John. Advertising, the Media and Globalisation: A World in Motion. New York: Routledge, 2012.

Williamson, Judith. Decoding Advertisements. London: Marion Boyars, 1978.

\section{(cc) BY-NC-ND}

Copyright (C) 2015 (John Sinclair). Media Industries is an open-access, peer-reviewed, online academic journal. As such, we aim to participate in the open exchange of information. This work is licensed under a Creative Commons Attribution Noncommercial No Derivatives (by-nc-nd) License. Under this license, this work is available for sharing and noncommercial distribution provided the appropriate attribution is given. 